\title{
WOMEN'S PERCEPTIONS OF MENOPAUSE AND ITS RELATIONSHIP TO THE MEANING OF LIFE AND THE CULTURE O FEAR
}

\author{
FLOR IVETT REYES GUILLÉN*
}

PhD from El Colegio de la Frontera Sur. Teacher-Researcher of the Faculty of Social Sciences of the Autonomous University of Chiapas, Mexico; President of the Research Network in Public Health and Care for Development Problems, REINVESAD; Research line: Cognitive Analysis for the Interpretation of Social Processes and Development; Society, Sustainability and Health; Member of the Academic Corps, Society, Culture, and Education; Calle Presidente Obregón s/n Fracc. Email: ivettrg017@gmail.com

Received: 22 June 2021, Revised and Accepted: 8 August 2021

\section{ABSTRACT}

In this article, an analysis of the results found in a research whose objective was to know the perceptions of women about menopause and its relationship with the culture of fear is presented. Information was obtained through structured interviews. The analysis focused on the recognition of its importance and the presence of fear before this stage of life. Likewise, the results were analyzed in relation to the importance of the meaning of life as the goal of human existence, without forgetting the relationship of this theme with fear. Fear was an agent of control of our aspirations and the identification of our scope. Important results were obtained in relation to both the fear of old age and the fear of death. A group of women under the age of forty and a group of women over the age of 40 years were interviewed. The young women who participated in the study expressed fear of death, and they are saddened to leave unfinished projects; while the fear reflected by older women generates that same sadness but directed only to the purely familiar aspects.

Keywords: Menopause, Meaning of life, Culture of fear, Old age, Quality of life.

(C) 2021 The Authors. Published by Innovare Academic Sciences Pvt Ltd. This is an open access article under the CC BY license (http://creativecommons.org/ licenses/by/4.0/) DOI: http://dx.doi.org/10.22159/ijss.2021v9i5.42504. Journal homepage: https://innovareacademics.in/journals/index.php/ijss

\section{INTRODUCTION}

The meaning of life, according to Frankl [1] consists of finding a purpose, the reason for living, and relates it closely to the ability to transcend self-transcend, intrinsic to the capacity of the human being to be able to self-evaluate. If we have that why then we find a how. This sense of life generates in us the freedom and motivation to carry out our dynamics, activities, and relationships, which begin from the good relationship with oneself. Specifically, on Logotherapy, it is a variant of psychotherapy, which is based on the will to sense as the first motivation of man. It is the third Viennese school framed in the field of psychology, the other two being the Psychoanalysis of Sigmund Freud [2] and the Individual Psychology of Alfred Adler [3].

While psychotherapy is focused on meaning, logotherapy emphasizes human orientation towards meaning. Since a person struggling to make sense of their life is not neurotic, they are not sick; but if there were neurosis it would be sociogenic because the frustration in the search for the meaning of life would reside in the social structure that contextualizes it [4]. Furthermore, we can identify the thread of the presence of fear in human life and even more so in current contexts, where, although in his time Frankl describes a context of war, today the context of human life is chaos, chaos in the strict sense of the word, chaos probably generated from a globalization.

The meaning of life is paramount, and it seems that today the structure of transmission of values and ideals, in societies, has suffered a strong fracture. However, it is the experiences of moments such as the one we live in worldwide, or the different stages of life we experience as individuals, that can give us the opportunity to reconnect our thoughts, with our ideals and actions, by individual and logically, collective senses.

Now, self-transcendence is the result of our thoughts, actions, and omissions. Moreover, it is also the result of having a sense of life [5]. These statements leave us in the position of analyzing the need to self-understand, that is, to form an opinion of ourselves, as people who interact with others, as much as by our human nature.

When several of the concepts that make societies, turn is shown without form, without foundation, without philosophical support, it is when we ask ourselves how complex it is to find a sense of life, interact with others, and not get lost in the ocean of possibilities of omission or infra or on valuation of purely material elements that, as Solorzano [6] mentions leave aside the condition of man as an integral being.

As for our specific theme, menopause, which does not only concern women over the age of 40 years but involves everyone because of the social synergy in which we live, it is common for people to feel old because of the number of years they have lived or without finding the logical order of things. However, it is important to keep in mind that old age, maturity, or youth, is not only marked by chronological age. While it is true that the human body is presenting changes over time, it is also true that these changes do not make it impossible to enjoy life and achieve your goals. Nor should the search for meaning of life be lost because we are mature or elderly, or because we believe that it is not important to be close to biological death.

It is then that it is not about what we experience during the aging process, but about the way in which we mentally and emotionally process the different phases and chronological stages of our life. How we live and how we transform our lives, as well as our ability to create positive environments or not, is how we will be identifying ourselves as human beings alive until the last moment of it and with the ability to transcend and leave death as a purely biological process.

\section{METHODS}

In the present study, a total of 100 women were interviewed, from the open population of San Cristóbal de Las Casas, Chiapas, Mexico, during the first quarter of 2020. The interviews were structured, based on a holistic, qualitative research model with a phenomenological approach 
and were aimed at two age groups of women, young women aged 1839 years (mean age 23 years) and 40 or more (mean age 62 years); for practical purposes, the first group will be called Group A and the group of 40 or more will be called Group B.

The questions that made up the interview included variables that could be answered for each age group, having variables in common that helped us to perform a comparative analysis and questions that apply only to women who were experiencing, or had experienced, the process of menopause.

\section{RESULTS}

\section{General data}

Religious affiliation: Catholicism in 92\%; 5\% Christians, 1\% Pentecostal; and $2 \%$ without religion.

Level of education: $4 \%$ have a postgraduate degree; $8 \%$ primary education; $10 \%$ secondary education; $1 \%$ without schooling and $77 \%$ with university level. It is important to mention that the percentage of women who have passed university education is high, even more so if we consider that Chiapas has poverty as one of the main factors linked to the educational backwardness. According to the National Institute for Adult Education [7] Chiapas is in the first places of educational backwardness in Mexico. In this state, $>50 \%$ of the population over 15 years of age, does not have secondary education $(1,900,000$ inhabitants).

Occupation: $16 \%$ are housewives, $16 \%$ are merchants, $8 \%$ are teachers, $6 \%$ are retirees, $8 \%$ are administrative staff, and $4 \%$ are employed in established shops. The remaining percentage, $58 \%$ are corresponds to university students.

\section{Perceptions about menopause}

About $6 \%$ of the interviewees think it is a good stage in their life because they stop menstruating. The remaining percentage (94\%) he perceives menopause as a very complicated stage because there are many changes that affect physically and emotionally and even perceive that woman are misunderstood at this stage and come to suffer depression.

\section{Feeling sad}

Regarding experiencing this emotion, 3\% mention that they have not felt sadness; however, $97 \%$ have experienced it; this percentage is associated with sadness with the death of a family member (9\%), with illnesses (9\%) and the remaining $82 \%$ relate it to multiple causes; but always related to the family.

\section{They are perceived to be successful}

About $44 \%$ of women $\geq 40$ years are not considered successful and in $\leq 39$ years only $20 \%$ are not considered successful $(12 \%$ under 20 years). About $100 \%$ associate's success with work achievements and with children they have or are scheduled to have in the future.

\section{Fear of old age, germanophobia}

About $68 \%$ of young women (Group A $\leq 40$ ) are not afraid of old age, emphasizing that it is a natural stage in everyone's life, and they want to reach that stage to see their achievements. The remaining percentage corresponds to women who fear old age because they believe they will be weaker at that stage.

About $15 \%$ of women in Group B ( $\geq 40$ years old) do not fear old age because it causes them to reach that age and enjoy seeing the growth of their children. The remaining percentage (85\%) fear old age because there are many limitations and diseases, they focus their fear on the health deficit and the increase in dependence on others.

It is important to mention that $30 \%$ of women over the age of 40 , say they feel young and the remaining percentage mentions that "they are already big." The great concept evades the condition of state of adulthood or old age and leaves it in a subjective connotation.

\section{Fear of death, tanatophobia}

Regarding this fear, young women (Group A $\leq 39$ ) who fear death represent $48 \%$, mostly due to the uncertainty it generates, the sadness of leaving their projects unfinished, and that their relatives suffer. The remaining percentage is not afraid of death because they consider it a natural process.

Of Group B ( $\geq 40$ years), $88 \%$ fear death, the causes of fear are related to purely family aspects. The $12 \%$ who do not fear death, affirm this reality with their religious faith.

\section{DISCUSSION}

Hormonal changes affect emotional stability, which generates situations of bad mood and hypersensitivity. These hormonal alterations are also in some cases, triggers of pathologies such as anxiety, depression, internal conflicts of identity, and self-esteem. This at the same time, if we do not have control over the situation, leads us to interpersonal conflicts that make the situation a woman goes through more complex [8-10]. Hence, a high percentage of the interviewees perceive this stage as an overly complicated stage because there are many changes that affect physically and emotionally.

Although the results show a high percentage of women who claim that they have experienced sadness, several scholars mention that "almost everyone thinks they know it is an emotion until they try to define it" [11] and sadness is precisely an emotion.

This leads us to talk about the psychology of emotions, one of the areas with many theories; but with less precise knowledge; perhaps by the very nature of the object of study. In this case, being addressing such an important topic within the area of health, it is worth mentioning that the area of emotions is one of the most interesting in research and for the medical area specifically in the promotion of health and the genesis of the disease [12]

It has been shown that emotional processes have relevance in alterations of the immune system, coronary disorders, diabetes, sleep, and pain disorders [13-16], to name just a few. This is how we question how important it is to attend to sadness, even more so in a menopausal period, which in most cases is associated with old age and hormonal disorders that can become severe. In this study, the relationship of sadness to family events such as death or illness is clear.

Nowadays, society conceptualizes success by relating it to economic growth, conceiving nature, the human itself as elements for development, growth, material empowerment. This is the mystification of success. Since its origin, the word success comes from the Latin exitus, which means the expiration of an adversity and therefore a culmination, an achievement [17].

On the other hand, and complementing this idea, we have emotional intelligence, which can recognize and regulate our emotions, that is, humans can have self-control, empathy, and good social relations. Given this, Goleman [18-20] affirms that this type of intelligence takes on greater importance than academic intelligence since it allows us to participate within the social fabric in which we are inserted and on it depends on the achievement of our actions, the growth, and the development of a harmonious and peaceful environment.

Therefore, we can think that in the XXI century, it is necessary to consider success as the series of actions that an individual performs to feed their emotional intelligence, generate harmonious and peaceful spaces, as well as self-evaluate and congratulate each of their daily achievements [21]. 
A phobia is an irrational fear that directly affects the quality of life of people who suffer from it [22]. In this case, gerontophobia is the fear of aging; people who experience it are horrified by the changes they undergo due to advancing age. Some changes they are afraid of may be becoming dependent on others, loss of mobility, changes in their appearance, and deteriorating health; most of these changes are those feared by the women who participated in the study. And this fear, associated with death is also present in this group.

\section{CONCLUSION}

Strictly with the process of menopause, we find elements that may be making our lives a full balance and the encounter of individual satisfaction and therefore enrichment of the collective; or, on the contrary, individual internal imbalance and therefore collective imbalance.

Being a woman within the premenopausal, menopausal, and climacteric process, implies a strong task to it. That is, women, at this stage of their lives, find the need to reaffirm themselves identity. In this search, he usually, in ordinary people, encounters strong conflicts in their sense of life. It is common for them to feel that they have closed different cycles, that death is approaching, that they have no place in family or social dynamics. But this is not the case, although not all countries have a cultural, philosophical, religious, attitudinal, and economic construct that includes adults, people in mature stages, or older adults as the source of the wisdom of a people. it is also true that not all individuals sit down to value their life, each act, each relationship. However, we all have enough elements to identify ourselves, constructions to share, and, of course, gaps to fill.

In the menopausal stage, making this reflection, individual and collective, is urgent, it is also extremely valuable to continue creating to continue living fully. It is necessary to rethink about our authenticity, how genuine we can be, and, above all, how much truth we walk day by day. Our ordinary life is the one that is transformed into a legacy, it is the one that is transformed into opportunities of transcendence, the one that, through the search and scope of our sense of life, projects through our actions, indisputable life lessons.

To talk about aging is to talk about a new way of life according to our needs, strengths, and limitations. It is important to recognize ourselves every day, to know what we have within reach and what is not, thus managing to adapt to the environment in which we operate.

It is undeniable the presence of fear before the changes experienced by the human being, in this case, the women interviewed evidence fear of physical, social, and emotional changes, which are presented as part of their aging felt or thought for a future. The fear of death is also a constant, more than in the unknown, the fear is to stop being and be spectators of when others cease to be.

\section{REFERENCES}

1. Frankl V. El Hombre En Busca Del Sentido. Germany: Herder; 1946.

2. Freud S. Psicoanálisis: Escuela Freudiana. Wentworth Press: Obras Completas; 1926. p. 2904-9.

3. Adler A. El Sentido de la Vida. Colección Austral. Spain: Espasa Calpe SA; 1921.

4. Rozo JA. Viktor Frankl (1905-1997) el sentido de la existencia. Rev Latinoam Psicol 1998;30:355-61.

5. Frankl V. Psicoterapia y Humanismo. Cambridge: FCE; 1982.

6. Solórzano HG. El hombre, un ser integral. Foro Educ 2008;6:347-67.

7. INEA. Instituto Nacional Para la Educación de Los Adultos; 2021. Available from: https://www.gob.mx/inea.

8. Freeman EW, Samuel MD, Lin H, Nelson DB. Associations of hormones and menopausal status with depressed mood in women with no history of depression. Arch Gen Psychyatry 2006;63:375-82.

9. Gyllstrom ME, Schereiner PJ, Harlow BL. Perimenopause and depression: Strength of association, causal mechanisms and treatment recommendations. Best Pract Res Clin Obstet Gynaecol 2007;21:275-92.

10. Sesma Pardo E, Finkle J, Gonzalez Torres MA, Gaviria M. Depresión perimenopáusica: Una revisión. Rev Assocc Esp Neuropsiq 2013;33:681-91.

11. Wenger MA, Jones FN, Jones MH. Physiological Psychology. Carlsbad: Holt Rinehart Winston; 1962.

12. Barragán Estrada AM, Morales Martínez CI. Psicología de las emociones positivas: Generalidades y beneficios. Enseñ Investig Psicol 2014;19:103-18.

13. Tejerizo LC, López-Sosa MC, Doyagüe MJ, Velasco MJ, Cabezas M, Lancharesta J. Aspectos psicológicos y psiquiátricos del climaterio. Clín Investig Ginecol Obstetr 1992;7:53-69.

14. Fernández-Abascal, E. Hipertensión, Intervención Psicológica. Eudema. Chinese: Debolsillo; 1993.

15. Fernández E, Magnani E, Fernández JM, Fernández-Arcilla Menopausia Qué Es? United States: Lilly. 2000

16. Larroy C, Gutiérrez S, León L. Tratamiento cognitivo-conductual de la sintomatología asociada a la menopausia. Avan Psicol Latinoam 2004;22:77-8.

17. London S, Formichella MM. El concepto de desarrollo de Sen y su vinculación con la educación. Econ Soc 2006;11:17-32.

18. Goleman D. In: Vergara J, editor. La Inteligencia Emocional. $2^{\text {nd }}$ ed. United Kingdom: BBC News; 1996.

19. Goleman D. In: Vergara J, editor. La Inteligencia Emocional En la Empresa. $3^{\text {rd }}$ ed. United Kingdom: BBC News; 2002.

20. Goleman D. El ABC de la Inteligencia Emocional. Tamil Nadu: Intermanagment; 2003.

21. Dueñas Buey ML. Importancia de la inteligencia emocional: Un nuevo reto para la orientación educativa. Educación 2002;21:77-96.

22. Chóliz M. Psicología de la Emoción: El Proceso Emocional; 2005. Available from: http://www.uv.es/=choliz. 